\begin{tabular}{|c|c|c|}
\hline \hline & $\begin{array}{c}\text { International Journal of Current Research in } \\
\text { Biosciences and Plant Biology }\end{array}$ \\
\hline EXCELLENT \\
PUBLISHERS
\end{tabular}

\title{
Improving the Nile Tilapia Production under Different Culture Systems
}

\author{
A. M. Abdelhamid ${ }^{1 *}$, M. A. Sweilum² and Marwa M. M. H. Zaher ${ }^{2}$ \\ ${ }^{1}$ Animal Production Department, Faculty of Agriculture, Mansoura University, Mansoura, Dakahlia Governorate 35516, Egypt \\ ${ }^{2}$ National Institute of Oceanography and Fisheries, Cairo, Egypt
}

*Corresponding author.

\section{Abstract}

Tow experiments were carried out on Nile tilapia (Oreochromis niloticus) fingerlings to evaluate the best stocking rate and the level of a dietary prebiotic, respectively to obtain good performance after 75 days of the rearing. The obtained results revealed that the lowest stocking rate $\left(5 \mathrm{fish} / \mathrm{m}^{3}\right)$ and the highest level of the prebiotic $(2 \mathrm{~g} / \mathrm{kg}$ diet) reflected the best results in most studied measurements for the nutrients utilization, carcass physical and chemical quality, and blood.

\section{Article Info}

Accepted: 21 February 2017

Available Online: 06 March 2017

\section{Keywords}

Dietary prebiotic

Nile tilapia

Oreochromis niloticus

Stocking density

\section{Introduction}

Tilapia is the second most important farmed fish in the world, after carps. Tilapia culture is being practiced in most of the tropical, subtropical and temperate regions. Great attention has been paid to tilapia culture in recent years (Osofero et al., 2009). Tilapias are versatile species now found in almost any tropical aquatic system (Beveridge and McAndrew, 2000). Tilapias have become increasingly popular for farming as they are able to reproduce rapidly, easily bred in captivity, tolerate to a wide range of environmental conditions, highly resistant to diseases, and most important of all, have good flavour. Though the fish originated in Africa, Asian countries have become the leading producers of these fishes (Rana, 1997). In fact, Nile tilapia, Oreochromis niloticus, has become one of the most commonly farmed freshwater fish species throughout the world, in particular (Popma and Masser, 1999).
The global production of tilapia is estimated to increase to about 8.9 million tones by the year 2020 (Tacon and Metian, 2008). However, in Egypt tilapia and mullet are considered the major cultured species, they contributed about $60.5 \%$ (557049 ton) and $12.6 \%$ (116029 ton) from the total aquaculture production (919585 ton) in 2010, respectively (GAFRD, 2010). So, increasing demand, however, necessitates that culture operations are not only optimized but expand to meet requirements. Improvements in knowledge of the factors affecting productivity is of great importance to the further development and success of tilapia culture (Coward and Bromage, 2000).

Nowadays Egypt is the $8^{\text {th }}$ country in the worldwide aquaculture production, the $2^{\text {nd }}$ (after China) in the worldwide tilapia production, and at the top in the worldwide mullet production (Elsharaky, 2016). Egypt 
produces yearly $c a$. 759.6 thousand ton of tilapia and 119.6 thousand ton of mullet from aquaculture only (Abogomaa, 2016).

Feed additives are substances added in trace amounts to a diet or feed ingredient either to preserve its nutritional characteristics prior to feeding, to facilitate ingredient dispersion or feed pelleting, to facilitate growth, to supply essential nutrients in purified form or to facilitate feed ingestion and consumer acceptance of the product. Feed additives are important in improved feed efficiency and animal performance (Stickney, 2000). Inulin and fructo-oligosaccharides are probably the most commonly used prebiotics. There is, however, general agreement on the major beneficial effects of prebiotics (Scheppach et al., 2001). Diet supplementation is an important aspect in aquaculture management especially in intensive or in semi-intensive fish culture and is promising for increasing fish production (Liti et al., 2005 and Abdel-Tawwab et al., 2007).

Prebiotics (dietary components such as complex carbohydrates able to change the colonic microenvironment fostering colonization with nonenteropathogens) are areas of current interest because they offer alternatives for the management of the growing problem of multiple antibiotic resistance and overwhelming infections (Josephlevy, 1998). Since, natural agriculture or organic farming is a return for the nature or working with, but not against, the nature (Abdelhamid, 2002). So, the macrobiotic management tools of probiotics, prebiotics and synbiotics have been developed and, indeed, commercialized over the few decades (Tuohy et al., 2003).

The present research aimed to study the effects of different graded levels of stocking densities (in the $1^{\text {st }}$ experiment) and various dietary graded levels of a prebiotic (POWER TOP, in the $2^{\text {nd }}$ experiment) on Nile tilapia fingerlings, concerning their growth performance, feed utilization, carcasscomposition, blood parameters and economics.

\section{Materials and methods}

In a cooperation between the Department of Animal Production, Faculty of Agriculture, Mansoura University and the National Institute of Oceanography and Fisheries, Ministry of Scientific Research, Cairo;the feeding experiment was carried out at the Research Station at the branch of Inland Water and Aquaculture
(QanaterKhiriah, Qaliobia governorate, Egypt), National Institute of Oceanography and Fisheries during summer season $\left(7^{\text {th }}\right.$ August $-23^{\text {nd }}$ October) 2016 (for 109 days, after 21 days as adaptation period).

The present study consisted of two experiments which were carried out under the same conditions in two concrete tanks $\left(4 \times 10 \times 1.25 \mathrm{~m}^{3}\right)$. Each concrete tank contains five Hapas $\left(4 \times 2 \times 1 \mathrm{~m}^{3}\right)$.The chemical and statistical analyses were carried out at the Department of Animal Production, Faculty of Agriculturt, Mansoura University.

\section{Experimental fish and management}

The first experiment was conducted to evaluate the effect of different stocking densities on Nile tilapia production:

\section{Stocking density was:}

$$
\begin{aligned}
& \text { 1- } 5 \text { fishes } / \mathrm{m}^{3} . \\
& \text { 2- } 7.5 \text { fishes } / \mathrm{m}^{3} \text {. } \\
& \text { 3- } 10 \text { fishes } / \mathrm{m}^{3} . \\
& \text { 4- } 12.5 \text { fishes } / \mathrm{m}^{3} \text {. } \\
& \text { 5- } 15 \text { fishes } / \mathrm{m}^{3} \text {. }
\end{aligned}
$$

Nile tilapia fingerlings of both sexes ( $23.3 \mathrm{~g}$ initial body weight and $11 \mathrm{~cm}$ initial body length) were obtained from Eliman Hatchery at Tolombat 7, Kafr EL-Sheikh governorate, Egypt for both experiments.

The basal diet used for the experimental fish was a commercial floating diet in a pelleted form $(3 \mathrm{~mm}$ diameter, from Feed Badrashin Factory, Giza governorate, Egypt, for the $1^{\text {st }}$ experiment but was ground to add the prebiotic and repelleted (in sinking form) in the $2^{\text {nd }}$ experiment) consists of yellow corn, soybean 46, full-fat soybean, soybean oil, dicalcium phosphate, lime stone, fish meal, appendages of wheat milling, rice bran, DDGS and common salt. It contains not less than $30 \%$ crude protein, not less than $5.5 \%$ crude fats, not more than $3.46 \%$ crude fibers, and not less than $3859 \mathrm{Kcal}$. ME/kg diet.

The experimental diets were offered twice daily (6 days / week) at a feeding rate of $3 \%$ of the actual fish biomass. The diets were offered daily at two meals ( 9 am and $1 \mathrm{pm})$.

The second experiment was conducted to evaluate the 
effect of different levels of a new prebiotic (POWER TOP from MEDIAVET, Kafr El-Sheikh Governorate, Egypt) on Nile tilapia production:

\section{Levels of prebiotic added to the diet were:}

$1-0 \mathrm{~g} / 1 \mathrm{~kg}$ diet.

2- $0.5 \mathrm{~g} / 1 \mathrm{~kg}$ diet.

$3-1 \mathrm{~g} / 1 \mathrm{~kg}$ diet.

4- $1.5 \mathrm{~g} / 1 \mathrm{~kg}$ diet.

$5-2 \mathrm{~g} / 1 \mathrm{~kg}$ diet.

Each one kilogram of the natural prebiotic contains $100 \mathrm{~g}$ Moss $(2,1 \beta$ glucan, $100 \mathrm{~g}$ formic acid, $100 \mathrm{~g}$ lactic acid, $100 \mathrm{~g}$ propionic acid, and silicate till $1000 \mathrm{~g}$ as given in the pamphlet of the product. The diets of the $2^{\text {nd }}$ experiment were prepared weekly.

Each experiment was carried out in 5 Hapas (each of $4 \times$ $2 \times 1 \mathrm{~m})$ per rectangular concrete tank $(10 \times 4 \times 1.25$ $\mathrm{m})$. The tanks were built outdoor. Fresh water was withdrawn into a precipitation earthen pond before pumped into the experimental concert tanks. The rearing water of each tank was partially changed twice weekly and totally each week to clean the tanks and Hapas.

\section{Experimental parameters measured}

\section{Physico-chemical properties of ponds' water}

One water sample/tank was taken biweekly for water analysis (water temperature, dissolved oxygen, $\mathrm{pH}$ value, ammonia and alkalinity) mid-day from $50 \mathrm{~cm}$ depth of the water column.

\section{Temperature}

Water temperature was measured during the time of sampling using Hydrolab model Orion Research Ion Analyzer 399A. Temperature is expressed as ${ }^{\circ} \mathrm{C}$.

\section{Hydrogen ion concentration-pH}

The $\mathrm{pH}$ value of the water samples was determined by means of Orion Research Ion Analyzer 399A pH meter.

\section{Dissolved Oxygen (DO)}

The "DO" of the water samples was measured using "Winkler method" as described below.
Principle: Addition of a divalent manganese salt to test water, it precipitates as $\mathrm{Mn}(\mathrm{OH})_{2}$, on addition of caustic soda solution containing $\mathrm{KI}, \mathrm{Mn}(\mathrm{OH})_{2}$ is oxidized quantitatively into higher manganese hydroxide by the dissolved oxygen. The addition of concentrated $\mathrm{H}_{2} \mathrm{SO}_{4}$ to initiate oxidation of iodide with higher manganese hydroxides leading to liberate iodine equivalent to dissolved oxygen. Titrate the liberated iodine against standard thiosulphate solution.

Procedure: To a water sample collected in $250-300 \mathrm{ml}$ DO bottle, $1 \mathrm{ml} \mathrm{MnSO}_{4}$ solution was added, followed by the addition of $1 \mathrm{ml}$ of alkaline iodide solution. Stopper was kept carefully to exclude air bubbles. By inverting bottle several times, the contents were well mixed and then $1-2 \mathrm{ml}$ conc. $\mathrm{H}_{2} \mathrm{SO}_{4}$ was added. Titrate the liberated iodine against standard thiosulphate solution $(0.025 \mathrm{~N})$ using starch as an indicator.

\section{Calculation}

$$
\text { DO }(\mathrm{mg} / \mathrm{l})=\mathrm{N} \times \mathrm{V} \times 8 \times 1000 / \mathrm{ml} \text { of sample }
$$

Where, $\mathrm{N}=$ normality of sodium thiosulphate $(0.025 \mathrm{~N})$; $\mathrm{V}=$ volume of standard sodium thiosulphate; $8=$ equivalent weight of $\mathrm{O}_{2}$.

\section{Carbonate alkalinity}

Principle: Alkalinity of water is its acid-neutralizing capacity. It is the sum of all the titrable bases. Both carbonate and bicarbonate were determined immediately after collection of the samples using phenolphthalein and methyl orange indicators. The measured value may vary significantly with the end point, $\mathrm{pH}$ used.

Procedure: To $25 \mathrm{ml}$ sample, three drops of phenolphthalein indicator was added; if the solution remains colorless this mean that carbonate alkalinity has not detected. If the sample turns fair pink color, the carbonate alkalinity was determined by titrating against $\mathrm{H}_{2} \mathrm{SO}_{4}(0.025 \mathrm{~N})$ until the pink color disappears.

\section{Calculation}

$\mathrm{CO}_{3}^{--}(\mathrm{mg} / \mathrm{l})=2 \mathrm{~A} \times \mathrm{N} \times 50 \times 1000 / \mathrm{ml}$ of sample

Where, $\mathrm{A}=$ volume of standard $\mathrm{H}_{2} \mathrm{SO}_{4} ; \mathrm{N}=$ normality of standard $\mathrm{H}_{2} \mathrm{SO}_{4}(0.025 \mathrm{~N}) ; 50$ = equivalent weight of $\mathrm{CO}_{3}{ }^{2-}$ expressed as $\mathrm{CaCO}_{3}$. 


\section{Bicarbonate alkalinity}

Procedure: To determine bicarbonate for the same sample, three drops of methyl orange indicator was added, then titrated against $\mathrm{H}_{2} \mathrm{SO}_{4}(0.025 \mathrm{~N})$ until the end point (wine red color) was obtained.

\section{Calculation}

$$
\mathrm{HCO}_{3}{ }^{-}(\mathrm{mg} / \mathrm{l})=(\mathrm{B}-2 \mathrm{~A}) \times \mathrm{N} \times 50 \times 1000 / \mathrm{ml} \text { of sample }
$$

Where, $\mathrm{A}=$ volume of standard $\mathrm{H}_{2} \mathrm{SO}_{4}$ in case of phenolphthalein indicator; $\mathrm{B}=$ total volume of standard $\mathrm{H}_{2} \mathrm{SO}_{4}$ after addition of methyl orange indicator; $\mathrm{N}=$ normality of standard $\mathrm{H}_{2} \mathrm{SO}_{4}(0.025 \mathrm{~N}) ; 50$ = equivalent weight of $\mathrm{HCO}_{3}{ }^{-}$expressed as $\mathrm{CaCO}_{3}$.

\section{Ammonia $\left(\mathrm{NH}_{4}{ }^{+}-\mathrm{N}\right)$}

Ammonia was determined using phenate method as described below.

Procedure: Standard solutions of ammonium chloride concentrations $(0-2 \mathrm{mg})$ were used for preparing the calibration curve and to find out the unknown sample concentration:

- To $50 \mathrm{ml}$ of sample $2 \mathrm{ml}$ phenol solution and $2 \mathrm{ml}$ of sodium nitroprusside solution were added.

- $5 \mathrm{ml}$ oxidizing solution $(100 \mathrm{ml}$ alkaline sodium citrate and $25 \mathrm{ml}$ sodium hypochlorite) was added immediately.

- Then the samples were covered with plastic wrap or paraffin wrapper and let color to develop at room temperature for at least one hour.

- The blue color produced was measured at a wavelength of $640 \mathrm{~nm}$ by Spectrophotometer model Jenway 6800UV/Vis double beam.

\section{Growth performance}

Biweekly samples (10 fish/Hapa) were taken to measure body weight and length to readjust the food quantity according to the actual bodyweight.

1- Growth in weight (g/fish).

2- Specific growth rate (SGR, \%/d)

$$
\mathrm{SGR}=100 \times\left\{\left(\mathrm{In} \mathrm{W}_{2}-\mathrm{In}_{1}\right) / \mathrm{T}\right\}
$$

Where, $\mathrm{W}_{2}$ is the final weight of fish $(\mathrm{g}), \mathrm{W}_{1}$ is the initial weight of fish $(\mathrm{g})$, In- is natural $\log$, and $\mathrm{T}$ is the period (day).

3- Relative growth rate (RGR, \%).

\section{Biological responses}

1- Condition factor $\left(\mathrm{K}_{\mathrm{f}}\right)$

$$
\mathrm{K}_{\mathrm{f}}=100 \times \text { Body weight, } \mathrm{g} /(\text { body length, } \mathrm{cm})^{3} .
$$

2- Hepatosomatic index (HIS)

$$
\text { HIS }=100 \times \text { liver weight/fish weight. }
$$

3- Gonadosomatic index (GSI)

$$
\text { GSI }=100 \times \text { Gonads weight } / \text { fish weight } .
$$

\section{Feed utilization}

1- Protein efficiency ratio $(\mathrm{PER})=$

PER = Weight gain $(\mathrm{g}) /$ Protein intake $(\mathrm{g})$.

2- Protein productive value (PPV, \%)

$\mathrm{PPV}=\{[$ Retained protein $(\mathrm{g})] /[$ Protein intake $(\mathrm{g})]\} \times 100$

3- Energy retention (ER, \%)

$\mathrm{ER}=\{($ Retained energy $) /($ Energy intake $)\} \times 100$.

\section{Carcass composition (\% DM basis) of fish flesh}

At the end of both experiments, 5 fish/Hapa were catched, weighed, and sampled for the following determinations and calculations of dry matter, crude protein, crude fat and ash content. At the end of all the feeding experiments, fish samples were weighed and killed. The viscera of five fishes were removed from the body and the carcasses were stored at $-20^{\circ} \mathrm{C}$. To obtain a homogenous material for chemical analysis, fish carcass of each group was homogenized by a mixer and stored at $-20^{\circ} \mathrm{C}$ until analysis. Two samples of the homogenized fish carcass materials and viscera were taken for determination of dry matter. Chemical analysis of food and fish carcass was carried out according to the methods described by A.O.A.C. (1990) for dry matter, crude protein, ether extract, crude fiber and ash. Nitrogen free extract (carbohydrate) content was 
calculated by subtraction the total percentages of $\mathrm{CP}$, $\mathrm{EE}, \mathrm{CF}$ and ash from 100. The gross energy contents of the experimental diets and fish samples were calculated by using factors of $5.65,9.45$ and $4.2 \mathrm{Kcal} / \mathrm{g}$ of protein, lipid and carbohydrate, respectively (NRC, 1993). Digestible energy content was calculated from standard physiological fuel values as 4,4 and $9 \mathrm{Kcal} / \mathrm{g}$ of protein, carbohydrate and lipid, respectively (Garling and Wilson, 1976). Metabolizable energy was calculated by using factors $3.49,8.10$ and $4.50 \mathrm{kcal} / \mathrm{g}$ for Total carbohydrates, $\mathrm{EE}$ and $\mathrm{CP}$, respectively according to Pantha (1982).

\section{Physical analysis of fish}

Water holding capacity (WHC \%) was calculated as 100 W2 / W1, where W1 and W2 are sample's weight before and after pressing with $5 \mathrm{Kgs}$ weight, respectively as cited from Abdelhamid (1983). Lean meat (LM \%) was also estimated using the equation cited from Pearson (1962) and Less (1968) where LM \% = 100 total meat nitrogen $\% / 3.9$.

\section{Blood hematology}

At the end of the experimental period, 10 fish from each of the treatments and control group were taken for physiological investigations. Fish were not fed for $24 \mathrm{~h}$ prior to blood sampling. Fish were anaesthetized using buffered tricaine methane sulfonate $(20 \mathrm{mg} / \mathrm{L})$ and blood was collected from fish heart by a sterile syringe. Blood samples were transferred into dry and clean tube with EDTA solution for measuring hemoglobin $(\mathrm{Hb})$, red blood cells (RBCs), and hematocrit (PCV) in blood after good mixing; RBCs counts $\left(\times 10^{6} / \mu \mathrm{l}\right)$, WBCs counts $\left(\times 10^{3} / \mu \mathrm{l}\right)$, hemoglobin content $(\mathrm{Hb}, \mathrm{g} / \mathrm{dl})$ and hematocrit value $(\%)$.

\section{Blood cell count}

Red blood cells count $\left(\mathrm{RBCs} \times 10^{6} / \mathrm{mm}\right)$ and white blood cells count (WBCs $\times 10^{3} / \mathrm{mm}$ ) were measured on an A bright- Line Haemocytometer model (Neubauer improved, Precicolor HBG, Germany) by using a commercial kits (Ranox Company, Germany) according to the method described by (Stopkopf, 1993). Where total erythrocytes count was performed simultaneously using the improved Neubauer chamber and Natt and Herrick solution as diluting fluid according to the method described by Natt and Herrick (1952), where the total number of red cells in five secondary squares were determined and multiplied by 10,000 . This value represents the total number of erythrocytes (RBC) per cubic millimeter of blood:

$$
\text { No. of erythrocytes } / \mathrm{mm}^{3}=(\mathrm{N} \times 200 \times 400 \times 10) / 80
$$

Where, $\mathrm{N}=$ Number of erythrocyte cells counted in 80 small squares

$200=$ Dilution factor

$400=$ Area of each small squares (tertiary squares)

$80=$ Number of small squares (tertiary)

\section{Determination of hemoglobin $(\mathrm{Hb})$}

The blood was treated with a reagent containing potassium ferricyanide, potassium cyanide and potassium dihydrogen phosphate. The ferricyanide reacts with blood forms methoglobin which was converted to cyanomethemoglobin by cyanide. The color obtained was measured spectrophotometerically at wave length $546 \mathrm{~nm}$ according to the method described by Zinkl (1986). Concentration of blood hemoglobin was calculated from the following equation:

Blood hemoglobin concentration $=\mathrm{A} \times 36.8=\mathrm{g} / \mathrm{dl}$

Where, $\mathrm{A}=$ Absorbance of sample.

\section{Packed cell volume (PCV \%)}

The packed cell volume (hematocrit \%) was measured using the microhaematocrit method (Decie and Lewis, 2006). The volume of the red cells as a percentage of the total volume of the blood was recorded as PCV\%.

\section{Blood biochemistry}

Blood serum was separated by centrifugation. Serum total protein $(\mathrm{g} / \mathrm{dl})$ was measured according to the method of Henry (1964) using reagent kits obtained from Diamond Diagnostic Company, Egypt; serum lipid $(\mathrm{mg} / \mathrm{dl})$ was determined by the method of McGowan et al. (1983); serum glucose (mg/dl) was estimated by the method described by Trinder (1969).

\section{Statistical analysis}

Data obtained were analyzed using one-way analysis of variance. All statistical analysis was performed 
according to SAS (2006). Differences were subjected to Duncan s (1955) multiple range tests.

\section{Results and discussion}

\section{Water quality criteria of the fish rearing}

The obtained results of fish rearing water criteria
(Tables 1 and 2) for both experiments were in the acceptable ranges suiting for tilapia culture as mentioned by Abdelhakim et al. (2002). However, Abou Zied et al. (2005) did not notice any effect of stocking density on water quality parameters. Yet, Hassan et al. (2006) and Bakeer et al. (2007) registered positive relationship between stocking density and water quality parameters.

Table 1. Mean values of fish rearing water's analyses for the $1^{\text {st }}$ experiment.

\begin{tabular}{llllll}
\hline Date & $\mathbf{p H}$ & Temperature, ${ }^{\circ} \mathbf{C}$ & Dissolved oxygen, mg/l & Ammonia, mg/l & Alkalinity, mg/l \\
\hline $7 / 8 / 2016$ & 7.6 & 24.2 & 2.0 & 0.241 & 414.8 \\
$22 / 8 / 2016$ & 7.8 & 29.4 & 2.0 & 0.244 & 274.5 \\
$7 / 9 / 2016$ & 7.8 & 28.8 & 8.4 & 0.427 & 378.2 \\
$25 / 9 / 2016$ & 8.0 & 27.4 & 12.4 & 0.355 & 330.0 \\
$10 / 10 / 2016$ & 7.6 & 27.0 & 6.5 & 0.118 & 343.4 \\
$23 / 10 / 2016$ & 7.9 & 24.6 & 5.9 & 0.274 & 205.6 \\
\hline
\end{tabular}

Table 2. Mean values of fish rearing water's analyses for the $2^{\text {nd }}$ experiment.

\begin{tabular}{llllll}
\hline Date & $\mathbf{p H}$ & Temperature, ${ }^{\circ} \mathbf{C}$ & Dissolved oxygen, mg/l & Ammonia, mg/l & Alkalinity, mg/l \\
\hline $7 / 8 / 2016$ & 7.6 & 24.2 & 2.0 & 0.241 & 414.8 \\
$22 / 8 / 2016$ & 7.7 & 29.7 & 2.2 & 0.371 & 305.0 \\
$7 / 9 / 2016$ & 8.0 & 29.9 & 8.0 & 0.132 & 402.6 \\
$25 / 9 / 2016$ & 7.9 & 27.4 & 12.6 & 0.180 & 319.6 \\
$10 / 10 / 2016$ & 7.5 & 26.6 & 6.6 & 0.091 & 354.4 \\
$23 / 10 / 2016$ & 7.9 & 24.6 & 3.5 & 0.417 & 195.2 \\
\hline
\end{tabular}

\section{Growth performance parameters}

The best final bodyweight, SGR, and RGR were obtained for treatment No.3 (10 fish $/ \mathrm{m}^{3}$, Table 3) in the $1^{\text {st }}$ experiment and for treatment No. 1 (control, $0 \mathrm{~g} / \mathrm{kg}$ diet, Table 4) for the $2^{\text {nd }}$ experiment. That means that the middle stocking rate as well as the control without the feed additive of the tested prebiotic.Growth performance was significantly decreased with increasing of the stocking density (Khouraiba et al., 1996). However, tilapia mean weight decreased curviliearly as the rate of stocking increased (Abdel-Aal et al., 2004; Bakeer et al., 2006). Moreover, there was a negative relationship between the logarithms of size and the logarithms of stocking density (Abdel-Aal et al., 2004 and Abou Zied et al., 2005). Zaki et al. (2002) and Kheir and Saad (2003) found too that increasing the stocking density led to decreased growth performance and feed and nutrients utilization significantly. In addition, Hassan et al. (2006) registered significant effect of stocking density on growth, since increasing density led to decreased body weight and length, relative growth rate, and daily gain. On the other hand, Abdelhamid (2011) concluded that high density of monoculture all males mono-sex Nile tilapia reflected better final bodyweight, bodyweight gain, average daily bodyweight gain, and specific growth rate.

Table 3. Mean values of the growth performance parameters for Nile tilapia throughout the $1^{\text {st }}$ experiment.

\begin{tabular}{lllllll}
\hline Treatment & IW, & FW, & TWG, & DWG, & SGR, \%/d & RGR, \% \\
\hline $\mathbf{1}$ & 24.5 & 70.2 & 45.7 & 0.586 & 2.4 & 186.5 \\
$\mathbf{2}$ & 20.0 & 75.2 & 55.2 & 0.708 & 2.4 & 276.0 \\
$\mathbf{3}$ & 22.5 & 84.5 & 62.3 & 0.799 & 2.5 & 280.6 \\
$\mathbf{4}$ & 26.8 & 88.7 & 61.9 & 0.794 & 2.5 & 231 \\
$\mathbf{5}$ & 26.2 & 67.0 & 40.8 & 0.523 & 2.3 & 155.7 \\
\hline
\end{tabular}


Table 4. Mean values of the growth performance parameters for Nile tilapia throughout the $2^{\text {nd }}$ experiment.

\begin{tabular}{lllllll}
\hline Treatment & IW, & FW, & TWG, & DWG, & SGR, \%/d & RGR, \% \\
\hline $\mathbf{1}$ & 21.0 & 95.5 & 74.5 & 0.955 & 2.5 & 354.8 \\
$\mathbf{2}$ & 22.3 & 85.9 & 63.6 & 0.815 & 2.5 & 285.2 \\
$\mathbf{3}$ & 26.5 & 94.3 & 67.8 & 0.869 & 2.5 & 2.5 \\
$\mathbf{4}$ & 25.4 & 92.9 & 67.5 & 0.865 & 2.9 & 2.4 \\
$\mathbf{5}$ & 19.7 & 79.4 & 59.7 & 0.765 & 303.1 \\
\hline
\end{tabular}

Amer (2012) concluded that Diamond V XP (inactive yeast a commercial product containing $100 \%$ dried Saccharomyces cerevisae) improves growth performance than control diet. Moreover, it could be suggested that dietary supplement with Diamond $V X P$ is useful in the intensive production system of fish. Lastly, Hassan (2013) showed that the probiotic Hydroyeast Aquaculture ${ }^{\circledR}$ realized best significant values for final body weight, average weight gain, average daily gain, relative growth rate, and specific growth rate of Nile tilapia. However, based on the obtained results, the optimum level of the tested probiotic Hydroyeast Aquaculture $^{\circledR}$ was depending on fish sex.

\section{Condition factor}

Mean values of the condition factor throughout both the experimental intervals are given in Tables 5 and 6 for both the $1^{\text {st }}$ and the $2^{\text {nd }}$ experiments, respectively. At the end of the whole experimental period, treatments No. 3 and 5 (10 and $15 \mathrm{fish} / \mathrm{m}^{3}$ stocking density) for the $1^{\text {st }}$ experimentand treatments No.1, 2 and 4 (0, 0.5, and 1.5 $\mathrm{g}$ prebiotic/kg diet) for the $2^{\text {nd }}$ experiment were the best. Bakeer et al. (2007) found a negative relationship between stocking rate on one side and body weight and length, daily gain, and specific growth rate, on the other side, but a positive relationship with condition factor.

Table 5. Mean values of the condition factor $(\%)$ for Nile tilapia throughout the $1^{\text {st }}$ experiment.

\begin{tabular}{llllll}
\hline \multirow{2}{*}{ Rearing days } & Treatment & \multicolumn{3}{l}{} & \\
\cline { 2 - 6 } & $\mathbf{1}$ & $\mathbf{2}$ & $\mathbf{3}$ & $\mathbf{4}$ & $\mathbf{5}$ \\
\hline $\mathbf{0}$ & 1.8 & 1.8 & 1.8 & 2.0 & 1.6 \\
$\mathbf{1 5}$ & 2.0 & 2.0 & 2.1 & 2.2 & 1.6 \\
$\mathbf{3 0}$ & 2.1 & 2.3 & 2.0 & 2.0 & 1.6 \\
$\mathbf{4 5}$ & 1.9 & 1.9 & 1.7 & 1.9 & 2.5 \\
$\mathbf{6 0}$ & 2.0 & 2.0 & 1.9 & 2.0 & 1.9 \\
$\mathbf{7 5}$ & 1.9 & 1.9 & 2.0 & 1.9 & 2.0 \\
\hline
\end{tabular}

Table 6. Mean values of the condition factor $(\%)$ for Nile tilapia throughout the $2^{\text {nd }}$ experiment.

\begin{tabular}{|c|c|c|c|c|c|}
\hline \multirow{2}{*}{ Rearing days } & \multicolumn{5}{|c|}{ Treatment } \\
\hline & 1 & 2 & 3 & 4 & 5 \\
\hline 0 & 2.0 & 1.8 & 1.8 & 1.8 & 1.8 \\
\hline 15 & 1.9 & 1.8 & 1.9 & 2.0 & 1.8 \\
\hline 30 & 1.9 & 1.9 & 1.9 & 2.0 & 1.9 \\
\hline 45 & 1.8 & 1.8 & 1.8 & 2.0 & 1.9 \\
\hline 60 & 2.0 & 1.9 & 1.8 & 1.8 & 2.0 \\
\hline 75 & 2.0 & 2.0 & 1.9 & 2.0 & 1.9 \\
\hline
\end{tabular}

Khalil (1999) indicated that total body length (TBL) and body weight $(\mathrm{BW})$ of tilapia were increased with advanced experimental periods without any negative effects of high level of dried live yeast (DLY). Also, it was noticed that DLY in the tested diets improved the most growth performance parameters recorded. In addition, Olvera et al. (2001) concluded that yeast have a positive effect on fish performance when cultured under stress condition of lowering dietary protein, leading to improving growth.Lara-Flores et al. (2003) stated that the increased growth rate as a positive response to added probiotics could be attributed to increased efficiency of existing digestive processes or by promoting the digestion of previously indigestible substances. In addition, probiotics may have a protein sparing effect. However, both Saccharomyces boulardii and Debaryomyces hansenii seemed to stimulate digestive maturation in fish. The supplementation of trout starter diet with $S$. boulardii may be particularly useful in fast growing conditions (Waché et al., 2006). 
Results revealed the superiority of the Avian Plus containing diets, which led to significantly best final bodyweight, average bodyweight gain, average daily bodyweight gain, relative growth rate, and specific growth rate comparing with the control (Abdelhamid et al., 2011). Recently, the probiotic Hydroyeast Aquaculture $^{\circledR}$ is useful for enhancing production performance of Nile tilapia (Khalil et al., 2013). Yet, Bio-Mos ${ }^{\circledR}$ and T-Protphyt 2000 revealed no significant differences among treatments concerning growth performance of the fish. However, the diet containing TProtphyt 2000 reflected the best growth performance. In conclusion, the dietary inclusion of Bio-Mos ${ }^{\circledR}$ was not beneficial, whereas the dietary inclusion of T-Protphyt 2000 was positively effective in increasing the growth performance of the tilapia fry (Abdelhamid et al., 2012).

\section{Internal organs' indices}

Table 7 presents the mean values of the HSI and GSI at the end of each experiment. Only the HSI for the 1st as well as the GSI for the 2nd experiment reflected significant differences among treatments in favor of treatment No. 5 and treatment No. 4, respectively.

Table 7. Mean values of the internal organs' indices [hepato-somatic index (HIS, \%) and gonado-somatic index (GSI, \%)] for Nile tilapia at the end of the $1^{\text {st }}$ and the $2^{\text {nd }}$ experiments.

\begin{tabular}{lllll}
\hline \multirow{2}{*}{ Treatment } & $\mathbf{1}^{\text {st }}$ experiment & & $\mathbf{2}^{\text {nd }}$ experiment & \\
\cline { 2 - 5 } & HSI & GSI & HSI & GSI \\
\hline $\mathbf{1}$ & $1.94^{\mathrm{b}}$ & 0.90 & 2.60 & $0.47^{\mathrm{b}}$ \\
$\mathbf{2}$ & $2.24^{\mathrm{ab}}$ & 1.02 & 2.12 & $0.64^{\mathrm{ab}}$ \\
$\mathbf{3}$ & $2.56^{\mathrm{ab}}$ & 1.57 & 2.64 & $0.60^{\mathrm{ab}}$ \\
$\mathbf{4}$ & $2.38^{\mathrm{ab}}$ & 0.40 & 2.64 & $0.80^{\mathrm{a}}$ \\
$\mathbf{5}$ & $2.98^{\mathrm{a}}$ & 0.76 & 2.70 & $0.51^{\mathrm{b}}$ \\
\hline
\end{tabular}

a-b: Means in the same column superscripted with different letters differ significantly $(p \leq 0.05)$.

\section{Nutrients utilization}

The experimental diet was initially analyzed. It contains $22.5 \pm 0.69 \%$ moisture, $77.6 \pm 0.68 \%$ dry matter, $40.5 \pm$ $0.06 \%$ crude protein, $5.90 \pm 0.25 \%$ crude fat, and $7.87 \pm$ $0.09 \%$ ash. However, the nutrients utilization at the end of both experiments was given in Tables 8 and 9, respectively. The lowest stocking density $\left(5 \mathrm{fish} / \mathrm{m}^{3}\right)$ and the highest rate of feed additive $(2 \mathrm{~g} / \mathrm{kg}$ diet $)$ were the best for all calculated parameters of nutrients utilization. Protein efficiency ratio was significantly decreased with increasing of the stocking density (Khouraiba et al., 1996). Additionally, El-Saidy and Gaber (2002) and Abou Zied et al. (2005) came to the same conclusions that growth performance and feed utilization were the best at the lowest stocking density.

Table 8. Mean values of the nutrients utilization parameters [protein efficiency ratio (PER), protein productive value (PPV) and energy retention (ER)] for Nile tilapia at the end of the $1^{\text {st }}$ experiment.

\begin{tabular}{llll}
\hline Treatment & PER & PPV, \% & ER, \% \\
\hline $\mathbf{1}$ & 15 & 8.3 & 3.02 \\
$\mathbf{2}$ & 11 & 6.0 & 2.05 \\
$\mathbf{3}$ & 9.2 & 5.2 & 1.79 \\
$\mathbf{4}$ & 6.9 & 3.6 & 1.43 \\
$\mathbf{5}$ & 6.8 & 3.7 & 1.51 \\
\hline
\end{tabular}

Table 9. Mean values of the nutrients utilization parameters [protein efficiency ratio (PER), protein productive value (PPV) and energy retention (ER)] for Nile tilapia at the end of the $2^{\text {nd }}$ experiment.

\begin{tabular}{llll}
\hline Treatment & PER & PPV, \% & ER, \% \\
\hline $\mathbf{1}$ & 22.9 & 11.9 & 4.71 \\
$\mathbf{2}$ & 24.0 & 14.0 & 4.41 \\
$\mathbf{3}$ & 21.2 & 11.0 & 4.43 \\
$\mathbf{4}$ & 18.3 & 9.20 & 3.79 \\
$\mathbf{5}$ & 26.8 & 15.0 & 6.30 \\
\hline
\end{tabular}


Khalil (1999) indicated that the dietary inclusion of dried live yeast significantly $(\mathrm{P}<0.01)$ improved nutrients utilization (protein productive value and energy utilization) more than those of the control diets.

Moreover, Olvera et al. (2001) indicated that there were clear differences among the treatments with probiotics and the control. The authors concluded that yeast have a positive effect on fish performance when cultured under stress condition of lowering dietary protein, leading to improving feed efficiency.Magouz et al. (2002b) concluded that adding Lacto-Saccto tilapia diet was the optimum for producing the best protein utilization. Also, El-Ebiary and Zaki (2003) showed that feed and nutrients utilization was improved with increasing the level of active yeast.Using pre-and probiotics improve the gut health (Tuohy et al., 2003). However, pronutrients can benefit animal health and performance through improving availability or utilization of nutrients in a variety of ways (Staykov et al., 2005). Therefore, El-Haroun et al. (2006) reported significantly enhancement in nutrients utilization (protein efficiency ratio, protein productive value, and energy retention) by Nile tilapia fed diets included Biogen ${ }^{\circledR}$ than the control. The prebiotic Avian Plus led to significantly best feed intake, protein intake, protein productive value, and protein efficiency ratio comparing with the control (Abdelhamid et al., 2011).

Amer (2012) concluded that Diamond V XP (inactive yeast) improves feed utilization than control diet. Also, Hassan (2013) and Khalil et al. (2013) showed that the probiotic Hydroyeast Aquaculture ${ }^{\circledR}$ realized best significant values for protein efficiency ratio.

\section{Fish carcass quality (physical and chemical)}

Date of carcass quality criteria including the dressing percentage, lean meat percentage, and water holding capacity percentage for both experiments is presented in Tables 10 and 11, respectively. The 1st treatment was the best in the 1st experiment (Table 10); whereas the $3^{\text {rd }}$ (in dressing \%), $2^{\text {nd }}$ and $5^{\text {th }}(\mathrm{LM} \%)$, and the $1^{\text {st }}, 2^{\text {nd }}$, and $5^{\text {th }}(\mathrm{WHC} \%)$ treatment were the best significantly.

Table 10. Mean values of the dressing \%, lean meat (LM) \%, and water holding capacity (WHC) \% for Nile tilapia at the end of the $1^{\text {st }}$ experiment.

\begin{tabular}{llll}
\hline Treatment & Dressing, $\%$ & Lean meat, $\%$ & WHC, $\%$ \\
\hline $\mathbf{1}$ & 83.0 & 54.5 & 76.5 \\
$\mathbf{2}$ & 82.9 & 53.2 & 72.9 \\
$\mathbf{3}$ & 81.9 & 51.2 & 74.2 \\
$\mathbf{4}$ & 82.6 & 53.3 & 76.1 \\
$\mathbf{5}$ & 81.4 & 51.2 & 75.1 \\
\hline
\end{tabular}

Table 11. Mean values of the dressing \%, lean meat (LM) \%, and water holding capacity (WHC) \% for Nile tilapia at the end of the $2^{\text {nd }}$ experiment.

\begin{tabular}{llll}
\hline Treatment & Dressing, \% & LM, \% & WHC, \% \\
\hline $\mathbf{1}$ & $80.0^{\mathrm{b}}$ & $48.4^{\mathrm{a}}$ & $76.1^{\mathrm{a}}$ \\
$\mathbf{2}$ & $81.3^{\mathrm{b}}$ & $48.8^{\mathrm{a}}$ & $75.4^{\mathrm{a}}$ \\
$\mathbf{3}$ & $83.6^{\mathrm{a}}$ & $41.4^{\mathrm{c}}$ & $71.1^{\mathrm{b}}$ \\
$\mathbf{4}$ & $80.6^{\mathrm{b}}$ & $45.9^{\mathrm{b}}$ & $71.3^{\mathrm{b}}$ \\
$\mathbf{5}$ & $80.8^{\mathrm{b}}$ & $49.9^{\mathrm{a}}$ & $76.4^{\mathrm{a}}$ \\
\hline
\end{tabular}

a-c: Means in the same column superscripted with different letters differ significantly $(p \leq 0.05)$.

The fish carcass was initially analyzed at the start of the experiment. It contains $80.2 \pm 0.12 \%$ moisture, $19.8 \pm$ $0.12 \%$ dru matter, $28.8 \pm 0.15 \%$ crude protein, $3.56 \pm$ $0.10 \%$ crude fat, and $13.7 \pm 0.55 \%$ ash. Whereas mean values of the proximate analysis for the experimented fish at the end of the $1^{\text {st }}$ and $2^{\text {nd }}$ experiments are given in Tables 12 and 13, respectively.There were significant differences among treatments for both experiments' fish in most contents. Significantly best DM was obtained in the $4^{\text {th }}$ treatment of both experiments. The significantly highest protein was in the $1^{\text {st }}$ treatment for the $1^{\text {st }}$ experiment but the significantly highest protein and lowest fat were realized in fish of the $2^{\text {nd }}$ treatment of the $2^{\text {nd }}$ experiment. 
Table 12. Mean values of the chemical composition (\% fresh wet basis) for Nile tilapia carcass at the end of the $1^{\text {st }}$ experiment.

\begin{tabular}{llllll}
\hline \multirow{2}{*}{ Criteria } & \multicolumn{7}{l}{ Treatment } & & & \\
\cline { 2 - 6 } & $\mathbf{1}$ & $\mathbf{2}$ & $\mathbf{3}$ & $\mathbf{4}$ & $\mathbf{5}$ \\
\hline Moisture & $76.6^{\mathrm{a}}$ & $73.1^{\mathrm{c}}$ & $74.9^{\mathrm{b}}$ & $72.6^{\mathrm{c}}$ & $75.0^{\mathrm{b}}$ \\
Dry matter (DM) & $23.4^{\mathrm{c}}$ & $26.9^{\mathrm{a}}$ & $25.1^{\mathrm{b}}$ & $27.4^{\mathrm{a}}$ & $25.0^{\mathrm{b}}$ \\
Protein & $24.0^{\mathrm{a}}$ & $20.4^{\mathrm{d}}$ & $22.2^{\mathrm{b}}$ & $19.9^{\mathrm{e}}$ & $22.0^{\mathrm{c}}$ \\
Fat & 10.2 & 10.2 & 10.1 & 10.1 & $11.0^{\mathrm{a}}$ \\
Ash & $5.44^{\mathrm{a}}$ & $4.41^{\mathrm{b}}$ & $5.20^{\mathrm{a}}$ & $3.83^{\mathrm{c}}$ & $5.00^{\mathrm{a}}$ \\
GE, Kcal/100g & 232.1 & 212.3 & 221.9 & 208.5 & 227.9 \\
ME, Kcal/100g & 175.3 & 161.7 & 168.2 & 159.0 & 173.6 \\
\hline
\end{tabular}

a-e: Means in the same row superscripted with different letters differ significantly ( $p \leq 0.05)$.

Table 13. Mean values of the chemical composition (\% fresh wet basis) for Nile tilapia carcass at the end of the $2^{\text {nd }}$ experiment.

\begin{tabular}{llllll}
\hline \multirow{2}{*}{ Criteria } & \multicolumn{5}{l}{ Treatment } \\
\cline { 2 - 6 } & $\mathbf{1}$ & $\mathbf{2}$ & $\mathbf{3}$ & $\mathbf{4}$ & $\mathbf{5}$ \\
\hline Moisture & $76.4^{\mathrm{d}}$ & $80.0^{\mathrm{b}}$ & $77.3^{\mathrm{c}}$ & $74.9^{\mathrm{e}}$ & $80.6^{\mathrm{a}}$ \\
Dry matter & $23.6^{\mathrm{b}}$ & $20.0^{\mathrm{d}}$ & $22.7^{\mathrm{c}}$ & $25.1^{\mathrm{a}}$ & $19.4^{\mathrm{e}}$ \\
Protein & $22.5^{\mathrm{d}}$ & $29.3^{\mathrm{a}}$ & $23.5^{\mathrm{c}}$ & $20.7^{\mathrm{e}}$ & $28.8^{\mathrm{b}}$ \\
Fat & $12.7^{\mathrm{a}}$ & $10.3^{\mathrm{c}}$ & $12.6^{\mathrm{a}}$ & $11.5^{\mathrm{b}}$ & $12.5^{\mathrm{a}}$ \\
Ash & $4.66^{\mathrm{c}}$ & $6.77^{\mathrm{a}}$ & $4.85^{\mathrm{c}}$ & $4.49^{\mathrm{c}}$ & $5.74^{\mathrm{b}}$ \\
GE, Kcal/100g & 247.5 & 263.0 & 251.7 & 226.0 & 281.0 \\
ME, Kcal/100g & 189.6 & 196.7 & 192.3 & 170.1 & 212.4 \\
\hline
\end{tabular}

a-e: Means in the same row superscripted with different letters differ significantly $(p \leq 0.05)$.

Carcass contents were unaffected by the stocking density (Khouraiba et al., 1996). Yet, Abdelhamid et al. (2012) showed that there were significant differences among the dietary treatments in the values of WHC and fat percentages, but not in DM and CP percentages. All the dietary treatments improved the WHC significantly comparing with the control. The highest fat and $\mathrm{CP}$ percentages were found in fry fish fed low level of BioMos®. The LM percentage did not differ significantly. Yet, significant differences among treatments could be shown in ash in the tilapia fry carcass. Negative and positive correlations were calculated between some tested physico-chemical parameters in the whole carcass of the experimented tilapia fry, but the significant ones were those between moisture and DM percentages, fat $\%$ and each of CP, ash, and LM, CP \% and each of ash, and LM, and between ash and LM. Significant differences were calculated among treatments in each of WHC, DM, and fat percentages. There were nonsignificant differences among treatments in ash and LM percentages. Negative and positive correlations between some tested physico-chemical parameters in the whole carcass of the experimented tilapia fry were calculated, but the significant ones were those between moisture and each of DM and fat percentages, DM and fat \%, CP and each of ash and LM, as well as between ash and LM. Particular significant ones were between WHC and each of fat and ash percentages, between moisture and DM percentages, fat and ash \%, CP \% and each of ash and LM percentages, and between ash and LM percentages (Abdelhamid et al., 2012).

For interpretation of these results, a negative relationship was noticed between $\mathrm{CP}$ and EE contents of fish body but a position relationship between $\mathrm{CP}$ and ash contents was recorded too (Abdelhamid et al., 2007b,c; El-Saidy and Gaber, 2002; El-Ebiary and Zaki, 2003). Yet, El-Saidy and Gaber (1998 and 2002) and El-Saidy et al. (1999) found a positive correlation between crude protein and fat contents of the fish. The obtained proximate analysis values are within the normal ranges given for tilapia by Ayyat et al. (2003) and Zaki (2004).

However, El-Saidy and Gaber (2002) and Zaki et al. (2002) found that whole body composition was significantly influenced by stocking density. Yet, ElSherif (2001) reported that stocking density seemed to have no significant effect on chemical composition of 
the prawn larvae whole body. Abdel-Aal et al. (2004) and Bakeer et al. (2006) found that the lowest stocking density of tilapia gave significantly the highest dressing percentage and flesh. Yet the highest stocking rate was responsible for the significantly highest crude protein and ash but the lowest ether extracts percentages, with a negative relationship between crude protein and ether extract percentages of the fish carcass.

In addition, Hassan et al. (2006) and Bakeer et al. (2007) registered significant effect of stocking density on carcass traits, since increasing density led to decreased dress-out, filet, edible parts. Abdelhamid et al. (2009) also fed African catfish fingerlings the local produced prebiotic (T-Protphyt 2000) which led to higher carcass protein, fat, and energy. Yet, El-Hais et al. (2011) found that dietary inclusion of digestamin did not influence tilapia carcass composition. However, Abdelhamid et al. (2014) reported that Aqua Superzyme affected the carcass composition, since all-males mono-sex Nile tilapia fish DM did not significantly $(p \geq 0.05)$ influence; yet, it was responsible for the highest $\mathrm{CP}$ and ash percentages and the lowest $\mathrm{EE}$ and energy contents.

Generally, there is a positive correlation between crude protein and crude ash contents of Nile tilapia fish, on the other hand (Abdelhamid et al., 2007a). A negative relationship was noticed between $\mathrm{CP}$ and EE contents of fish body but a position relationship between CP and ash contents was recorded too (El-Saidy and Gaber, 2002).
Abdelhamid et al. (2002a,b, 2004), Abdelhamid (2005a,b), Goda (2002), Magouz et al. (2002a,b) and ElEbiary and Zaki (2003) found a negative correlation between protein and fat contents of the fish.Moreover, Khattab et al. (2004a) and El-Haroun (2007) reported that dietary inclusion of Biogen ${ }^{\circledR}$ significantly increased crude protein content and decreased total lipids in whole fish body of Nile tilapia and African catfish, respectively. The probiotic Hydroyeast Aquaculture ${ }^{\circledR}$ is useful for enhancing production performance Nile tilapia (Khalil et al., 2013). Also, Abdelhamid et al. (2009) showed that increasing the probiotic level increased fish carcass protein, fat and energy contents.

\section{Blood picture}

Data of blood analysis is presented in Tables 14 and 15 for the hematological parameters and in Tables 16 and 17 for the biochemical parameters of $1^{\text {st }}$ and $2^{\text {nd }}$ experiments, respectively.The $1^{\text {st }}$ experiment reflected significant differences among treatments in all tested hematological (Table 14) and some tested biochemical (Table 16) parameters, where the lower stocking densities were significantly the best ones. But the used prebiotic at the highest level led to significantly the best HCT\% and lymphocytes \% (Table 15) as well as blood glucose (Table 17). The obtained blood values are within the normal ranges given for tilapia by Hussein and Mekkawy (2001), Ayyat et al. (2003), and Hussein and Kobeisy (2001).

Table 14. Mean values of the hematological parameters for Nile tilapia at the end of the $1^{\text {st }}$ experiment.

\begin{tabular}{|c|c|c|c|c|c|}
\hline \multirow{2}{*}{ Parameter } & \multicolumn{5}{|c|}{ Treatment } \\
\hline & 1 & 2 & 3 & 4 & 5 \\
\hline $\mathrm{Hb}, \mathrm{g} / \mathrm{dl}$ & $10.0^{\mathrm{a}}$ & $8.70^{b}$ & $9.77^{\mathrm{ab}}$ & $8.70^{b}$ & $9.63^{a b}$ \\
\hline $\mathrm{RBCs} \times 10^{6} / \mathrm{mm}^{3}$ & $1.55^{\mathrm{bc}}$ & $1.12^{\mathrm{c}}$ & $2.20^{\mathrm{a}}$ & $1.88^{\mathrm{ab}}$ & $2.03^{\mathrm{ab}}$ \\
\hline $\mathrm{HCT}, \%$ & $27.7^{\mathrm{a}}$ & $19.5^{\mathrm{b}}$ & $27.8^{\mathrm{a}}$ & $25.9^{\mathrm{a}}$ & $27.5^{\mathrm{a}}$ \\
\hline $\mathrm{MCV}$ & $179.2^{\mathrm{a}}$ & $175.2^{\mathrm{a}}$ & $129.8^{b}$ & $138.1^{\mathrm{b}}$ & $137.4^{b}$ \\
\hline $\mathrm{MCH}$ & $64.9^{a b}$ & $81.7^{\mathrm{a}}$ & $45.5^{\mathrm{b}}$ & $46.1^{\mathrm{b}}$ & $48.0^{\mathrm{b}}$ \\
\hline $\mathrm{MCHC}$ & $40.1^{\mathrm{ab}}$ & $46.4^{\mathrm{a}}$ & $35.2^{\mathrm{b}}$ & $33.5^{\mathrm{b}}$ & $35.0^{\mathrm{b}}$ \\
\hline P. $\times 10^{3} / \mathrm{mm}^{3}$ & $106^{\mathrm{a}}$ & $52.3^{\mathrm{b}}$ & $29.3^{\mathrm{b}}$ & $37.3^{b}$ & $35.3^{b}$ \\
\hline WBCs $\times 10^{3} / \mathrm{mm}^{3}$ & $153.7^{\mathrm{a}}$ & $143.3^{a b}$ & $153.7^{\mathrm{a}}$ & $135.0^{\mathrm{b}}$ & $147.7^{\mathrm{a}}$ \\
\hline N., $\%$ & 2.33 & 2.67 & 3.00 & 3.33 & 3.67 \\
\hline L., $\%$ & 93.0 & 92.3 & 93.7 & 93.0 & 92.3 \\
\hline M., \% & 3.67 & 4.00 & 2.33 & 2.67 & 3.00 \\
\hline
\end{tabular}

Hb: hemoglobin, RBCs: red blood cells, HCT: hematocrit, MCV: mean corpuscular volume, MCH: mean corpuscular hemoglobin, MCHC: mean corpuscular hemoglobin concentration, P.: platelets, WBCs: white blood cells, N.: neutrophil, L.: lymphocytes, M.: monocytes. a-b: Means in the same column superscripted with different letters differ significantly $(p \leq 0.05)$. 
Table 15. Mean values of the hematological parameters for Nile tilapia at the end of the $2^{\text {nd }}$ experiment.

\begin{tabular}{|c|c|c|c|c|c|}
\hline \multirow{2}{*}{ Parameter } & \multicolumn{5}{|c|}{ Treatment } \\
\hline & 1 & 2 & 3 & 4 & 5 \\
\hline $\mathrm{Hb}, \mathrm{g} / \mathrm{dl}$ & 10.6 & 10.2 & 10.1 & 9.27 & 10.6 \\
\hline $\mathrm{RBCs} \times 10^{6} / \mathrm{mm}^{3}$ & 2.16 & 2.11 & 1.92 & 1.85 & 2.19 \\
\hline HCT, \% & $31.6^{\mathrm{a}}$ & $31.4^{\mathrm{a}}$ & $30.7^{\mathrm{ab}}$ & $27.3^{b}$ & $33.6^{\mathrm{a}}$ \\
\hline $\mathrm{MCV}$ & 148.0 & 149.0 & 160.7 & 148.6 & 153.5 \\
\hline $\mathrm{MCH}$ & 49.6 & 48.3 & 52.9 & 50.2 & 48.2 \\
\hline $\mathrm{MCHC}$ & $33.5^{\mathrm{a}}$ & $32.5^{\mathrm{ab}}$ & $32.9^{a b}$ & $33.9^{\mathrm{a}}$ & $31.5^{b}$ \\
\hline P. $\times 10^{3} / \mathrm{mm}^{3}$ & 30.3 & 38.3 & 34.0 & 31.7 & 30.3 \\
\hline $\mathrm{WBCs} \times 10^{3} / \mathrm{mm}^{3}$ & $169.5^{\mathrm{a}}$ & $168.8^{\mathrm{a}}$ & $170.6^{\mathrm{a}}$ & $149.2^{b}$ & $168.0^{\mathrm{a}}$ \\
\hline N., \% & $5.00^{\mathrm{a}}$ & $3.33^{b}$ & $3.00^{\mathrm{b}}$ & $4.00^{\mathrm{ab}}$ & $2.67^{\mathrm{b}}$ \\
\hline L., \% & $92.0^{\mathrm{b}}$ & $92.7^{b}$ & $93.0^{\mathrm{ab}}$ & $92.7^{b}$ & $94.3^{\mathrm{a}}$ \\
\hline M., \% & 2.00 & 3.00 & 3.00 & 2.67 & 2.00 \\
\hline
\end{tabular}

Hb: hemoglobin, RBCs: red blood cells, HCT: hematocrit, MCV: mean corpuscular volume, MCH: mean corpuscular hemoglobin, MCHC: mean corpuscular hemoglobin concentration, P.: platelets, WBCs: white blood cells, N.: neutrophil, L.: lymphocytes, M.: monocytes.a-b: Means in the same column superscripted with different letters differ significantly ( $p \leq 0.05$ ).

Table 16. Mean values of the blood biochemical parameters for Nile tilapia at the end of the $1^{\text {st }}$ experiment.

\begin{tabular}{llllll}
\hline \multirow{2}{*}{ Parameter } & Treatment & \multicolumn{3}{l}{} \\
\cline { 2 - 6 } & $\mathbf{1}$ & $\mathbf{2}$ & $\mathbf{3}$ & $\mathbf{4}$ & $\mathbf{5}$ \\
\hline Total protein, g/dl & 3.45 & 3.18 & 3.11 & 3.48 & 3.06 \\
Albumin, g/dl & 1.41 & 1.38 & 1.40 & 1.48 & 1.37 \\
Globulin, g/dl & 2.04 & 1.80 & 1.71 & 2.00 & 1.69 \\
Glucose, $\mathrm{mg} / \mathrm{dl}$ & $171.0^{\mathrm{c}}$ & $203.3^{\mathrm{c}}$ & $337.0^{\mathrm{a}}$ & $211.3^{\mathrm{bc}}$ & $299.0^{\mathrm{ab}}$ \\
Total lipids, $\mathrm{mg} / \mathrm{dl}$ & $438.0^{\mathrm{bc}}$ & $507.7^{\mathrm{b}}$ & $404.0^{\mathrm{c}}$ & $528.7^{\mathrm{b}}$ & $657.7^{\mathrm{a}}$ \\
\hline
\end{tabular}

a-c: Means in the same column superscripted with different letters differ significantly $(p \leq 0.05)$.

Table 17. Mean values of the blood biochemical parameters for Nile tilapia at the end of the $2^{\text {nd }}$ experiment.

\begin{tabular}{llllll}
\hline \multirow{2}{*}{ Parameter } & Treatment & & & \\
\cline { 2 - 6 } & $\mathbf{1}$ & $\mathbf{2}$ & $\mathbf{3}$ & $\mathbf{4}$ & $\mathbf{5}$ \\
\hline Total protein, g/dl & 3.82 & 3.93 & 4.13 & 4.00 & 3.97 \\
Albumin, g/dl & $1.38^{\mathrm{bc}}$ & $1.62^{\mathrm{a}}$ & $1.22^{\mathrm{c}}$ & $1.58^{\mathrm{a}}$ & $1.48^{\mathrm{ab}}$ \\
Globulin, g/dl & 2.44 & 2.31 & 2.91 & 2.42 & 2.49 \\
Glucose, $\mathrm{mg} / \mathrm{dl}$ & $169.3^{\mathrm{b}}$ & $223.3^{\mathrm{ab}}$ & $244.0^{\mathrm{ab}}$ & $247.0^{\mathrm{ab}}$ & $339.3^{\mathrm{a}}$ \\
Total lipids, $\mathrm{mg} / \mathrm{dl}$ & $726.0^{\mathrm{a}}$ & $663.0^{\mathrm{ab}}$ & $607.3^{\mathrm{b}}$ & $639.7^{\mathrm{b}}$ & $649.7^{\text {ab }}$ \\
\hline
\end{tabular}

a-b: Means in the same column superscripted with different letters differ significantly $(p \leq 0.05)$.

Kobesiy and Hussein (1995) used Oreochromis niloticus to determine the effect of live yeast on some blood constituents. They concluded that live yeast (LY) may improve blood constituents of $O$. niloticus, and dietary LY is useful in stress condition, particularly in the case of $\mathrm{O} 2$ deficiency due to water pollution and intensive production. Also, Stosik and Szenfeld (1996) found that Cerbio as a commercial probiotic increased immunlogical blood indices. Moreover, Sahan and Duman (2008) found that haematocrit, leucocytes, monocytes, and neutrophils were increased in common carp fed with beta glucan. Also, Aly et al. (2008c)showed significant increase in haematocrit values in group of Nile tilapia fed the mixture of $B$. subtilis and L. acidophilus comparing with the control. Abdelhamid et al. (2009) also fed African catfish fingerlings the local produced prebiotic (T-Protphyt 2000) which led to higher counts of RBCs, WBCs, and platelets, and albumin/globulin ratio, decreased blood proteins. The prebiotics T-Protphyt 2000 and Bio-Mos ${ }^{\circledR}$ (Abdelhamid et al., 2009 and 2012) improved the fish performance as a consequence of the positive effects of 
the prebiotics on fish health and resistance. Recently, Hassan (2013) showed that probiotic Hydroyeast Aquaculture ${ }^{\circledR}$ realized best significant values for RBCs and WBCs counts and PCV \% compared with the control group.

\section{Conflict of interest statement}

Authors declare that they have no conflict of interest.

\section{References}

A. O. A. C., 1990. Official Methods Analysis of Association of Official Analytical Chemists. $15^{\text {th }}$ Edn. Published by the Association of the Analytical Chemists, North Nineteenth St. Auite 210 Arlingth, Virginia 2220 / USA.

Abdel-Aal, M.M., Hassan, A.A., Mahmoud, A.A., 2004. Effect of stocking density on growth performance and body composition of Nile tilapia (Oreochromis niloticus) in rice fields. Proc. $1^{\text {st }}$ Intern. Conf. Vet. Res. Div., NRC, Cairo, Egypt, Feb. 15-17 ${ }^{\text {th }}$. pp.384392.

Abdelhakim, N.F., Baker, M.N., Soltan, M.A., 2002. Aquatic Environment for Fish culture. Cairo, (ISBN: 977 - $298-228-5$ ).

Abdelhamid, A. M., 1983. Studies on 16-week old chicks of Dandarawi and Leghorn. In: Proceedings of the $29^{\text {th }}$ European Congress of Meat Researcher Workers, Salsomaggiore. pp.1-14. (Fleischwirtsch., 64: 74, 1984).

Abdelhamid, A. M., 2011. Intensive rearing of monosex Nile tilapia and silver carp under mono-or polyculture systems at different stocking densities in floating net cages. engormix.com, Aquaculture Technical Article, 9 p. (J. Anim. Poult. Prod., Mansoura Univ. 2, 277-289).

Abdelhamid, A. M., Abd El-Khalek, A. E., Mostafa, M. A. A., Gomaah, S. A. A., Khalil, F. F. M., 2004. Effect of using Betafin ${ }^{\circledR}$ and/ or Biobolym ${ }^{\circledR}$ as natural additives in producing Nile tilapia fish in poly-culture semi-intensive system in earthen ponds. J. Agric. Sci. Mansoura Univ. 29, 3149-3162.

Abdelhamid, A. M., Ibrahim, M. A., Naghraby, N. A., Soliman, A. A. A., 2007a. Effect of dietary supplementation of betaine and/or stocking density on performance of Nile tilapia. J. Agric. Sci. Mansoura Univ. 32, 167-177.

Abdelhamid, A. M., Mehrim, A. I., El-Barbary, M. I., Ibrahim, S. M., Abdel-Wahab, A. I., 2009. Evaluation of a new Egyptian probiotic by African catfish fingerlings. J. Environ. Sci. Technol. 2(2), 133-145.

Abdelhamid, A. M., Soliman, A. A. A., Maghraby, N. A., 2011. Evaluation of using the prebiotic avian plus in tilapia fish diet. Egypt. J. Nutr. Feeding. 14 (3), 537-546.

Abdelhamid, A.M., 2002. Organic Farming. Proc. $2^{\text {nd }}$ Conf. Food borne Contamination and Egyptian's Health, April 23-24, Mansoura Faculty of Agriculture. pp.69-77.

Abdelhamid, A.M., 2005a. Carcinogens. Darannashr for Universities. Cairo, Deposit No. 1949/2005.

Abdelhamid, A.M., 2005b. Legislations controlling fisheries in Egypt. Al- Saiad, 33, 4- 83 -

Abdelhamid, A.M., Khalil, F.F.M., El-Barbary, M.I., Zaki, V.H., Husien, H.S., 2002a. Feeding Nile tilapia on Biogen ${ }^{\circledR}$ to detoxify aflatoxic diets. Proc. $1^{\text {st }}$ Ann. Sc. Conf. Anim. \& Fish Prod. Mansoura, $24 \& 25$ September. pp.207-230.

Abdelhamid, A.M., Magouz, F.I., Salem, M.F.E., Mohamed, A.A., Mohsen, M.K., 2002b. Effect of dietary graded levels of aflatoxin B1 on growth performance and biochemical, chromosomal and histological behaviour of Nile tilapia, Oreochromis niloticus. Proc. $1^{\text {st }}$ Ann. Sc. Conf. Anim. \& Fish Prod. Mansoura, 24 \& 25 September. pp.231-250.

Abdelhamid, A.M., El-Barbary, M. I., Hasan, M. M. M., 2012. Effect of dietary supplementation with Bio$\operatorname{mos}{ }^{\circledR}$ or T-protphyt 2000 with and without hormone treatment on performance, chemical composition, and hormone residues of mono-sex Nile tilapia. J. Anim. Poult. Prod. Mansoura Univ. 3, 99-113.

Abdelhamid, A.M., El-Fadaly, H.A., Ibrahim, S.M., 2007c. Integrated aquaculture by bearing ducks on earthen fish ponds. engormix.com. Aquaculture Technical Articles.

Abdelhamid, A.M., El-Fadaly, H.A., S.M. Ibrahim, H.A., 2007b. Studies on integrated fish/duck production system: 1- On water quality and fish production. J. Agric. Sci. Mansoura Univ. 32, 5225 5244.

Abdelhamid, A.M., Mehrim, A.I., Seden, M.E.A., Zenhom, O.A., 2014. Effect of different sources and levels of some dietary biological additives on: IIIbody composition of Nile Tilapia fish. Egypt. J. Aquat. Biol. Fish. 18(1), 13-24.

Abdel-Tawwab, M., Abdel-Ghany, A. E., Ahmad, M. H., 2007. Effect of diet supplementation on water quality, phytoplankton community structure, and the growth of Nile tilapia, Oreochromis niloticus 
(L.), common carp, Cyprinus carpio L., and silver carp, Hypophthalmichthys molitrix V. polycultured in fertilized earthen ponds. Journal of Applied Aquacult. 1, 1-24.

Abogomaa, S., 2016. Egyptian aquaculture production.Personal communication, Facebook on 19/11/2016.

Abou Zied, R.M.; Abd El-Maksoud, A.M.S. and Ali, A.A.A. (2005).Effect of stocking rates of Nile tilapia (Oreochromisniloticus L.) and grey mullet (Mugilcephalus L.) on their performance in polyculture earthen ponds. Annals of Agric. Sc., Moshtohor, 43 (3): 1057-1066.

Aly, S.M., Ahmed, Y.A. Ghareeb, A.A. and Mohamed, M.F. (2008c).Studies on Bacillus subtilis and Lactobacillus acidophilus, as potential probiotics, on the immune response and resistance of tilapia nilotica (Oreochromisniloticus) to challenge infections. Fish and Shellfish Immunology, 25: 128 $-136$.

Amer, A.A.A.M. (2012). Effect of different levels of protein and probiotics on productive performance of fresh water fishes. M.Sc., Fac. Agric., Kafrelsheikh Univ.

Ayyat, M.S.; Sharaf, S.M., Abbas, F.S. and El-Marakby, H.I. (2003).Reduction of dietary lead toxicity in Nile tilapia (Oreochromisniloticus). Egyptian J. Nutrition and Feeds, 6 (Special Issue): 419-431.

Bakeer, M.N.; Mahmoud, A.A., Radwan, M.I. and Hassan, A.A. (2006). Growth performance and survival of Nile tilapia seeds (Oreochromisniloticus) reared in concrete tanks during winter season under different stocking densities. J. Agric. Sci. Mansoura Univ., 31 (5): 2719-2731.

Bakeer, M.N.; Mostafa, M.A.A. and Higaze, A.Z. (2007).Effect of fish size and density at initial stocking on growth performance and fish marketable size. J. Agric. Sci. Mansoura Univ., 32 (3): 18031813.

Beveridge, M.C.M. and McAndrew, B.J. (eds) (2000). Tilapias: biology and exploitation. Kluwer, Dordrecht.

Coward, K. and Bromage, N.R. (2000).Reproductive physiology of female tilapia broodstock. Reviews in Fish Biology and Fisheries, 10: 1-25.

Decie, S. I. V. and Lewis, S. M. (2006).Practical Hematology. $10^{\text {th }}$ Edn., Churchill Livingstone, London. ISBN: 13: 978- 443, PP: 736.

Duncan, D. (1955). Multiple range tests and multiple Ftests. Biometrics, II: 1-42.

El-Ebiary, E.H. and Zaki, M.A. (2003).Effect of supplementing active yeast to the diets on growth performance, nutrient utilization, whole body composition and blood constituents of monosex Nile tilapia (Oreochromisniloticus). Egypt. J. Aquat. Biol. \& Fish., 7(1): 127-139.

El-Hais, A.M.A.; Khalafalla, M.M.F. and Shalaby, S.M.M. (2011).Effect of different levels of digestamin supplementation on performance of Nile tilapia (Oreochromisniloticus) fingerlings. Egyptian J. Nutrition and Feeds, 14 (2): 319-326.

EL-Haroun, E.R. (2007). Improved growth rate and feed utilization in farmed African catfish Clariasgariepinus (Burchell 1822) thought a growth promoter Biogen ${ }^{\circledR}$ supplementation. Journal of Fisheries and Aquatic Science, 2: 319-327.

EL-Haroun, E.R., Goda, A. MA-S and KabirChowdhury, M.A. (2006).Effect of dietary probiotic Biogen ${ }^{\circledR}$ supplementation as a growth promoter on growth performance and feed utilization of Nile tilapia Oreochromisniloticus (L.). Aquaculture Research, 37: 1473-1480.

El-Saidy, D.M.S.D. and Gaber, M.M.A. (1998). Effects of using ascorbate polyphosphate in practical diets on Nile tilapia (Oreochromisniloticus) fry performances. Menofiya J. Agric. Res., 23(2): 363 -378 .

El-Saidy, D.M.S.D. and Gaber, M.M.A. (2002). Intensive culture of Nile tilapia, Oreochromisniloticus in concrete tanks in Egypt: effect of stocking density and feeding levels on growth performance, production traits feed conversion and body composition. Proc. 1st Sc. Conf. Aqua., El-Arish, 13-15 Dec., 22p.

El-Saidy, D.M.S.D., Gaber, M.M.A. and Magouz, F.I. (1999).Effect of dietary energy level on growth, feed conversion, body composition, digestibility coefficients and energy budget of Nile tilapia (Oreochromisniloticus). Egypt. J. Aquat. Biol. \& Fish., 3(3): 159-178.

Elsharaky, A. (2016). Egyptian aquaculture production among the world production.Personal communication, Facebook on 19/11/2016.

El-Sherif, M.S. (2001). Studies on growth performance of prawn (Macrobrachiumrosenbergii) as affected by with type of feeding and stocking density. J. Agric. Sci. Mansoura Univ., 26 (7): 4177-4185.

GAFRD (2010).General Authority for Fish Resources Development.The $2010 \quad$ Statistics Yearbook.Ministry of Agriculture and Land Reclamation Publications Cairo Egypt, 96 p.

Garling, D. L. and Wilson, R. P.(1976). Optimum 
dietary protein to energy ratio for Channel catfish fingerlings, Ictaluruspunctatus. Journal of Nutrition, (106) : 1368-1375.

Goda, A.M.A.S. (2002). The influences of n6/n3 dietary fatty acid ratio on growth performance and body fatty acid composition of Nile tilapia (Oreochromisniloticus). Vet. Med. J. Giza, 50(1): $33-45$.

Hassan, A.S.; Hassan, A.A. and Mahmoud, S.H. (2006).Effect of stocking rate and organic fertilization on the growth performance of tilapia aurea (Oreochromisaureus). J. Agric. Sci. Mansoura Univ., 31 (2): 617-625.

Hassan, M.E.M. (2013). Physiological Studies on Fish Production. M.Sc. Thesis, Fac. Agric., Al-Mansoura Univ.

Henry, R. J. (1964). Colorimetric determination of total protein. In: Clinical Chemistry. Harper and Row Publ., New York, USA.

Hussein, S.Y. and Kobeisy, M.A. (2001). Influence of dietary zinc and vitamin A levels on growth performance, blood constituents and immune competence of Nile tilapia, Oreochromis niloticus under upper Egypt conditions. Assiut Vet. Med. J., 45 (90): 55-74.

Hussein, S.Y. and Mekkawy, I.A.A. (2001).The effect of lead-exposure, and lead-clay interaction on the growth performance, biochemical and physiological characteristics and histopathology of Tilapia zillii. Bull. Fac., Assiut Univ., 30 (1-E): 65-97.

Josephlevy, M. D. (1998). Immunonutrition: The Pediatric Experience. Nutrition, 14 (7/8): 641- 647.

Khalil, F.F.M. (1999). Effect of varying dietary protein sources and levels on growth performance and feed utilization of tilapia fish (Oreochromisniloticus). Egypt. J. Nut. Feeds . 2: 99 - 109.

Khalil, F.F.M.; Mehrim, A.I. and Hassan, M.E.M. (2013). Effect of Hydroyeast Aquaculture as growth promoter for adult Nile tilapia Oreochromisniloticus.Engormix.com, 10 p.

Khattab, Y.A.E., Mohsen, A. and Ahmed, M.H. (2004a). Effect of protein level and stocking density on growth performance, survival rate, feed utilization and body composition of Nile tilapia fry (Oreochromisniloticus L.). Proceedings of $6^{\text {th }}$ International Symposium on Tilapia in Aquaculture, Roxas Boulevard, Manila, Philippines, pp. 264-276.

Kheir, M.T. and Saad, A.S. (2003). Growth performance and feed utilization of Oreochromisniloticus (Linnaeus, 1757) fingerlings as affected with stocking density and feeding regime. J. Egypt. Acad.
Soc. Environ. Develop., (B-Aquaculture), 4 (2): 121.

Khouraiba, H.M.; El-Sherif, M.S. and Al-Farsi, E.M. (1996).Effect of stocking density and dietary protein level on growth performance and feed utilization of shrimp, Penaeus japonicas juvenile, in nursery system. Egypt. J. Appl. Sc., 11 (11): 262-284.

Kobeisy, M.A. and Hussein, S.Y. (1995). Influence of dietary live yeast on growth performance and some blood constituents in Oreochromisniloticus. Proc. 5th Sci. Conf. Anim. Nut., Ismailia, $12-13$ Dece.,pp: $417-425$.

Lara- Flores, M.; Olvera - Novoa, M.A.; Guzman Mendez, B.E. and Lopez-Madrid, VV. (2003).Use of the bacteria Streptococcusfaeciun and Lactobacilli acidophilus, and the yeast Saccharomyces cerevisiae as growth promoters in Nile tilapia (Oreochromisniloticus).Aquaculture, 216: 193- 201.

Less, R. (1968).The Laboratory Handbook of Methods of Food Analysis.Leonard Hill Books, London.

Liti, D. Cherop, L., Munguti, J. and Chhorn, L.,(2005). Growth and economic performance of Nile tilapia (Oreochromis niloticus L.) feed on two formulated diets and two locally available feeds in fertilized ponds. Aquaculture Research 36:746-752.

Magouz, F.I., Mohsen, M.K. and Abd El-Moniem, N.M. (2002-a).Utilization of different sources and levels of lipids in the diet of Nile tilapia (Oreochromisniloticus). Proc. 2nd Conf. Foodborne Contamination and Egyptians' Health, 23-24 April, El-Mansoura, Egypt, pp: 357-370.

Magouz, F.I., Mohsen, M.K. and Gooda, A.H. (2002b).Effect of including some biological feed additives in the diet on growth performance and feed efficiency of Nile tilapia (Oreochromisniloticus). Proc. 2nd Conf. Foodborne Contamination and Egyptians' Health, April 23 - 24, El-Mansoura Univ., pp: 329 - 339.

McGowan, M.W.; Artiss, J.D., Standbergh, D.R. and Zak, B.A. (1983).Peroxidase-coupled method for colorimetric determination of serum triglycerides.Clin. Chem., 29: 538.

National Research Council, (NRC) (1993).Nutrient Requirements of fish.National academy press. Washington. DC.

Natt, M.P. and Herrick, C.A. (1952).A new blood diluent for counting erythrocytes and leucocytes of the chicken. Poultry Science, 31, 735-738.

Olvera. M.A., Lara. M.; Guzman, B.E. and Lopez, W.G. (2001). Effect of the use of probiotics on the growth 
of tilapia Oreochromis niloticus reared under stress condition. Aquaculture -Book of abstracts 143-J.M. Parker -Coliseum- Louisiana state Univ. BatonRouge -LA -70803 - USA. World - Aquaculture Society.

Osofero, S. A., Otubusin, S. O. and Daramola, J. A. (2009).Effect of stocking density on tilapia (Oreochromis niloticus Linnaeus 1757) growth and survival in bamboo-net cages trial. African Journal of Biotechnology, 8 (7): 1322-1325.

Pantha, B. (1982). The use of soybean in practical feeds for Tilapia niloticus. M.Sc. Thesis. Univ. of Stirling.

Pearson, D. (1962). The Chemical Analysis of Food. J. $\&$ A. Churchill LTD, London.

Popma, T. and Masser, M. (1999). Tilapia: Life History and Biology. Southern Regional Aquaculture Center.No. 283. pp. 1-4.

Rana, K.J. (1997). Global Overview of production and production trends. In: Reviews of the state of world Aquaculture. FAO Fisheries Circular 886, Rome.163 pp.

Sahan, A. and Duman, S. (2008). Effects of diet with $\beta$ 1,3/1,6 glucan on some haematological parameters in common carp (Cyprinuscarpio L., 1758) infected by ecto-parasites. Proc.Of Middle East \& North Africa Conf. for Future of Animal Wealth, Cairo, Egypt, 16-18 Oct.

SAS (2006).SAS statistical guide for personal computer, SAS Institute Inc. Cary, NC.

Scheppach, W., Luehrs, H., and Menzel, T. (2001). Beneficial health effects of low-digestible carbohydrate consumption. British Journal of Nutrition, 85 (Suppl. 1), 823-930.

Staykov, Y., Spring, P. and Denev, S. (2005). Influence of dietary Bio-Mos ${ }^{\circledR}$ on growth, survival and immune status of rainbow trout (Salmogairdneriirideus G.) and common carp (Cyprinuscarpio L.). Nutrional Biotechnology in the Feed and Food Industries: Proceedings of Alltech's $21^{\text {th }}$ Annual Symposium, Nottingham University
Predd, UK, pp: 333-343.

Stickney.R. (2000). Encyclopedia of aquaculture.John Wiley \& Sons, Inc.

Stopkopf, M. K. (1983). Avian haematology in clinical practice. Med. Vet. Pract., 64: 713-717.

Stosik, M. and Szenfeld.J. (1996).Use of Cerbio probiotic in carp nutrition.Medycyna • Weterynaryjna, 52: 467-469.

Tacon, A.G.J. and Metian, M. (2008). Global overview on the use of fish meal and fish oil in industrially compounded aquafeeds: trends and future prospects. Aquaculture, 285: 146-158.

Trinder, P. (1969). Determination of glucose in blood glucose oxidase with an alternative oxygen acceptor. Ann. Clin. Biochem., 6: 24.

Tuohy, K. M., Probert, H. M., Smejkal, C. W. and Gibson, G. R. (2003).Using probiotics and prebiotics to improve gut health. DDD, 8: $692-700$ (www.drugdiscoverytoday.com).

Waché, Y., Auffray, F., Gatesoupe, F.J., Zambonino, J., Gayet, V., Labbé, L. and Quentel, C. (2006). Cross effects of the strain of dietary Saccharomyces cerevisiae and rearing conditions on the onset of intestinal microbiota and digestive enzymes in rainbow trout, Onchorhynchusmykiss, fry. Aquaculture, 258: 470-478.

Zaki, M.A. (2004). Growth performance, feed utilization and carcass composition comparisons of monosex tilapia (Oreochromisniloticus) produced by various techniques. J. Agric. Sci. Mansoura Univ., 29 (8): 4115-4125.

Zaki, M.A.; Mabrouk, H.A. and Nour, A.A. (2002).Optimum dietary protein level and stocking density for fresh-water prawn (Macrobrachiumrosenbergii) juvenile rearing in concrete basins. Egyptian J. Anim. Prod., 39 (2): 161-168.

Zinkl, J. G (1986). Avian hematology. In: Jain NC (Edd. Schalms Veterinary Hematology, Philadelphia, Paihea and Febiger. pp.256-260.

\section{How to cite this article:}

Abdelhamid, A.M., Sweilum, M.A., Zaher, M.M.M.H., 2017. Improving the Nile tilapia production under different culture systems. Int. J. Curr. Res. Biosci. Plant Biol. 4(3), 41-56. doi: https://doi.org/10.20546/ijcrbp.2017.403.005 